\title{
SIFAT MEKANIK MEMBRAN BERBASIS PADUAN KITOSAN SUKSINAT-KITOSAN TERINSERSI LITIUM
}

\section{(MECHANICAL PROPERTIES OF MEMBRANE BASED ON POLYBLEND OF CHITOSAN SUCCINATE-CHITOSAN OBTAINED BY INSERTION LITHIUM)}

\author{
L.O.A.N Ramadhan', S. H. Sabarwati, Amiruddin, Harniati dan Susanti \\ Jurusan Kimia Fakultas MIPA Universitas Halu Oleo, Kendari \\ Kampus Hijau Bumi Tri Dharma Anduonohu, Kendari, 93231 \\ E-mail : ramadhan305@gmail.com
}

Received : 30 September 2014 ; revised : 5 Oktober 2014 ; accepted : 16 Oktober 2014

\begin{abstract}
ABSTRAK
Sifat mekanik merupakan salah satu karakter yang penting dalam pengembangan material polimer fungsional seperti membran elektrolit yang berpotensi untuk penghantar litium. Dalam penelitian yang telah dilakukan, membran elektrolit disintesis dengan bahan dasar kitosan suksinat dan kitosan, serta litium. Membran dipreparasi melalui metode inversi fasa dengan variasi komposisi fraksi massa kitosan suksinat dan kitosan. Selanjutnya dilakukan uji sifat mekanik. Hasil penelitian menunjukkan bahwa peningkatan fraksi massa kitosan suksinat sampai dengan $60 \%$ (b/b) cenderung meningkatkan kekuatan tarik dan perpanjangan, serta menurunkan Modulus Young. Pada fraksi massa kitosan suksinat $70 \%$ sampai dengan $80 \%$ (b/b), kekuatan tarik dan perpanjangan cenderung menurun, serta Modulus Young meningkat. Nilai maksimum kekuatan tarik, perpanjangan, dan Modulus Young masing-masing adalah 0,18 MPa, $112 \%$, dan 14,31 MPa. Berdasarkan hasil analisis sifat mekaniknya, membran paduan kitosan suksinat-kitosan terinsersi litium memiliki stabilitas mekanik yang cukup baik.
\end{abstract}

Kata kunci: Paduan, Kitosan suksinat, Kitosan, Litium, Sifat mekanik

\section{ABSTRACT}

Mechanical properties is one of the important character in the development of functional materials such as polymer electrolyte membrane that potential for lithium conductor. In this research, electrolyte membrane based on chitosan succinate and chitosan, as well as lithium was synthesized. The membranes were prepared by phase inversion method with a variation of the composition of the mass fraction of chitosan succinate and chitosan, then testing in the mechanical properties. Results of study showed that the increase in mass fraction of chitosan succinate up to $60 \%(w / w)$ tends to increase the tensile strength and elongation, and decrease the Young's modulus. At the mass fraction of chitosan succinate $70 \%$ to $80 \%(w / w)$, tensile strength and elongation tend to decrease, and the Young's modulus increases. The maximum value of tensile strength, elongation, and Young's modulus of each is $0.18 \mathrm{MPa}, 112 \%$, and $14.31 \mathrm{MPa}$. Based on the results of mechanical properties analysis, polyblend membrane of chitosan succinate-chitosan obtained by insertion lithium has a good mechanical stability.

Keywords: Blend, Chitosan succinate, Chitosan, Lithium, Mechanical properties.

\section{PENDAHULUAN}

Kebutuhan akan sumber energi yang terus meningkat sebagai akibat semakin menipisnya cadangan minyak bumi yang menyebabkan terjadinya krisis energi khususnya energi listrik. Energi listrik merupakan energi yang sangat diperlukan bagi manusia, bahkan sebagian besar aktivitas manusia ditunjang dengan sebuah peralatan dan teknologi yang menggunakan listrik sebagai sumber energi. Salah satu sumber energi alternatif yaitu baterai. Baterai merupakan sumber energi yang paling murah dan praktis dan merupakan suatu rangkaian sel elektrokimia yang tersusun dari katoda, anoda dan elektrolit yang mampu menghasilkan energi listrik dengan potensial tertentu. Baterai yang umum dijumpai pada alat- 
alat portable masa kini adalah baterai litium (Winter and Brood, 2004).

Awalnya baterai litium menggunakan elektrolit dalam bentuk larutan. Namun, hal tersebut menimbulkan berbagai kerugian seperti kurang praktis, mudah bocor dan mudah terkorosi. Maka elektrolit dalam bentuk cairan mulai ditinggalkan dan beralih pada elektrolit bermatriks padatan polimer sebagai penghantar ion. Baterai litium dengan elektrolit padatan polimer disebut baterai polimer litium.

Baterai polimer litium menggunakan elektrolit polimer kering yang berbentuk seperti lapisan film tipis. Lapisan film ini disusun berlapis-lapis diantara anoda dan katoda yang mangakibatkan pertukaran ion (Meyer, 1998). Jenis polimer yang telah digunakan sebagai matriks adalah kitosan-litium (Mohammed et al., 1995), PMM (Polymethyl methacrylate) dan PVDF (Polyvinyl diflouride) (Xiao et al., 2008). Banyak penelitian yang dilakukan untuk mencari membran elektrolit alami yang memiliki kemampuan setara dengan PMM dan PVDF dengan biaya produksi yang murah.

Salah satu senyawa polimer alam yang dapat digunakan sebagai membran polimer elektrolit bermatriks padatan penghantar proton yaitu kitosan (Wan et al, 2003). Kitosan memiliki sisi aktif berupa gugus amina $\left(-\mathrm{NH}_{2}\right)$ dan hidroksil $(-\mathrm{OH})$ yang memberikan karakteristik sebagai penukar ion (Rinaudo, 2006, Wan et al, 2003,). Namun demikian dalam keadaan normal, kitosan memiliki konduktivitas listrik yang rendah karena kitosan tidak dapat diimobilisasi di bawah pengaruh medan listrik untuk menghasilkan konduktor proton (Mukoma et al., 2004). Selain itu, kerapatan energi membran kitosan masih relatif rendah dan hidrofilisitasnya yang masih tinggi sehingga nilai konduktivitasnya masih relatif rendah untuk diaplikasikan dalam baterai polimer litium.

Sementara itu, modifikasi kitosan dengan anhidrida suksinat akan meningkatkan kerapatan muatan, dapat menghasilkan senyawa kitosan suksinat yang tidak mudah larut dengan derajat subtitusi yang tinggi, dengan gugus - $\mathrm{COOH}$ rantai ujung yang mudah terionisasi sehingga berpotensi menjadi penghantar ion (Ramadhan et al, 2012). Dengan potensinya sebagai penghantar ion, material tersebut perlu dimodifikasi dan dimanfaatkan sebagai material alternatif seperti penghantar ion litium pada rangkaian membran elektroda dalam baterai polimer litium dan memperbaiki sifat mekanik membran.

Sifat mekanik merupakan salah satu karakter yang penting dalam pengembangan material polimer fungsional seperti membran elektrolit yang berpotensi untuk penghantar ion litium. Oleh karena itu, dilakukan penelitian ini untuk mengetahui sifat mekanik membran elektrolit berbasis kitosan suksinat-kitosan terinsersi litium.

\section{BAHAN DAN METODE}

\section{Bahan}

Bahan yang digunakan dalam penelitian ini adalah kitosan (massa molekul $305 \mathrm{kDa}$ ), anhidrida suksinat, metanol, etanol, aseton, $\mathrm{NaOH}$ teknis, $\mathrm{NaOH}$ p.a, asam asetat, aseton, akuades, $\mathrm{LiNO}_{3}$, dimetyhylformamide, $\mathrm{HCl}, \mathrm{H}_{2} \mathrm{SO}_{4}$, asam oksalat.

\section{Metode}

Pembuatan membran kitosan suksinatkitosan litium diawali dengan melarutkan kitosan dengan asam asetat $2 \%$ sebanyak $50 \mathrm{~mL}$, diaduk dengan pengaduk magnet selama 24 jam. Kitosan suksinat hasil sintesis berdasarkan metode Noerati et al, 2007, dilarutkan dalam 50 $\mathrm{mL}$ asam asetat $2 \%$ dan diaduk dengan pengaduk magnet selama 24 jam. Larutan campuran kitosan suksinat-kitosan ditambahkan masing-masing $\mathrm{LiNO}_{3} \quad 0,8 \quad \mathrm{~g}$, serta diaduk menggunakan pengaduk magnet sampai homogen. Larutan dope kitosan suksinat-kitosan litium dicetat dalam cetakan poliakrilat kemudian didiamkan pada suhu ruang sampai diperoleh membran paduan yang siap dikarakterisasi.

Tabel 1. Komposisi variasi massa membrane paduan kitosan suksinat-kitosa litium dengan berat total $2,5 \mathrm{~g}$

\begin{tabular}{cccc}
\hline $\begin{array}{c}\text { Membran } \\
(\%)\end{array}$ & $\begin{array}{c}\text { Massa } \\
\text { Kitosan } \\
\text { Suksinat, g }\end{array}$ & $\begin{array}{c}\text { Massa } \\
\text { Kitosan } \\
\mathbf{g}\end{array}$ & $\begin{array}{c}\text { Massa } \\
\text { LiNO }_{3}, \mathbf{g}\end{array}$ \\
\hline KS-K (80:20) & 2,00 & 0,50 & 0,80 \\
KS-K (70:30) & 1,75 & 0,75 & 0,80 \\
KS-K (60:40) & 1,50 & 1,00 & 0,80 \\
KS-K (50:50) & 1,25 & 1,25 & 0,80 \\
KS-K (40:60) & 1,00 & 1,50 & 0,80 \\
KS-K (30:70) & 0,75 & 1,75 & 0,80 \\
KS-K (20:80) & 0,50 & 2,00 & 0,80 \\
KS-K (10:90) & 0,25 & 2,25 & 0,80 \\
\hline
\end{tabular}

\section{Karakterisasi.}

Untuk menganalisis kekuatan mekanik dari membran berbasis paduan kitosan suksinatkitosan litium dikarakterisasi melalui uji tarik. Selain itu, dilakukan analisis daya serap air.

\section{Uji Tarik.}

Pengukuran kuat tarik (tensile strength), perpanjangan (elongation), dan Modulus Young dilakukan dengan menggunakan alat uji tarik merk Shimadzu AGx 690, sensitivitas 1/1000, beban maksimum 1 ton, kecepatan minimum 10 
$\mathrm{mm} / \mathrm{s}$ dan kecepatan maksimum $25 \mathrm{~mm} / \mathrm{s}$. Membran hasil sintesis yang telah disimpan dalam wadah kedap udara yang berisi silika gel dipotong menyerupai dumbbell seperti pada Gambar 1.

Membran diuji kekuatan tarik dengan kecepatan tarik $10 \mathrm{~mm} /$ menit. Kedua ujung sampel dijepit pada alat uji tarik, lalu sampel ditarik sampai putus. Besarnya gaya tarik yang diberikan $(\mathrm{kgF})$ dan perpanjangan membran $(\Delta \mathrm{l})$ dicatat.

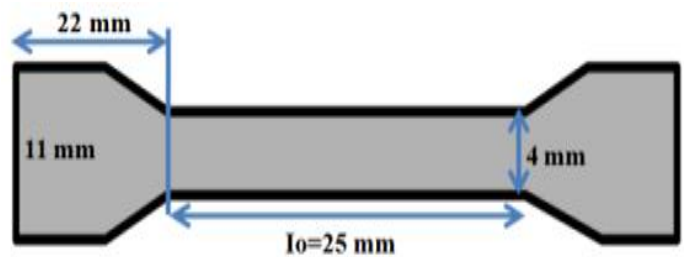

Gambar 1. Bentuk sampel untuk uji tarik

\section{HASIL DAN PEMBAHASAN}

\section{Pembuatan Membran Kitosan Suksinanat- Kitosan Terinsersi Litium}

Pembuatan membran kitosan suksinatkitosan litium dilakukan dengan inversi fasa, yaitu proses transformasi polimer dari fasa cair ke fasa padat dengan penguapan pelarut (Mulder, 1996), tahapannya yaitu dengan membuat larutan kitosan suksinat dan larutan kitosan yang homogen, kemudian kedua larutan tersebut dicampur dan ditambahkan litium nitrat. Selanjutnya dilakukan pencetakan larutan kitosan suksinat-kitosan litium pada cetakan poliakrilat, serta penguapan pelarut. Membran kitosan suksinat-kitosan terinsersi litium terlihat pada Gambar 2.

Membran kitosan suksinat-kitosan yang terinsersi litium diperoleh membran dengan ketebalan berkisar 0,0130-0,017 cm. Penampakan secara visual, membran yang dihasilkan bersifat transparan.

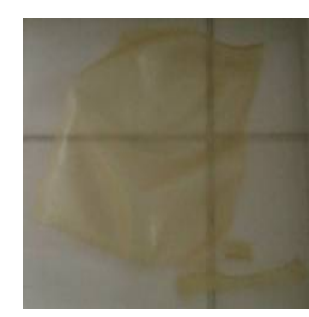

Membran Kitosan -Li

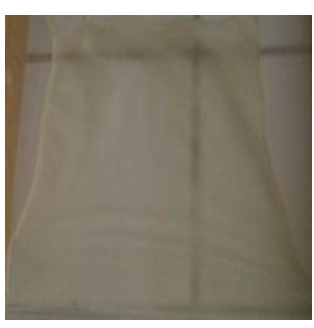

Membran KS-K(60:40)

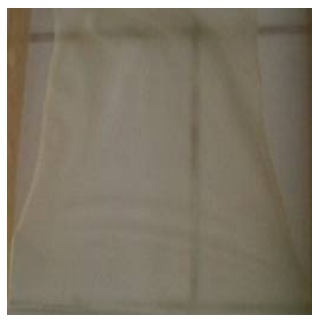

Membran KS-K(30:70)

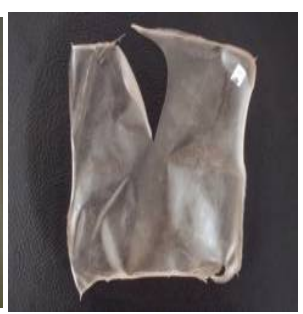

Membran KS-K(80:20)

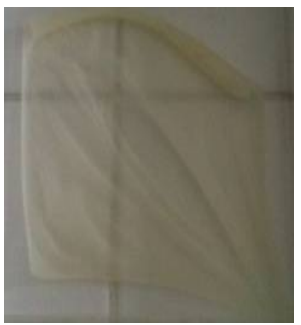

Membran KS-K(50:50)

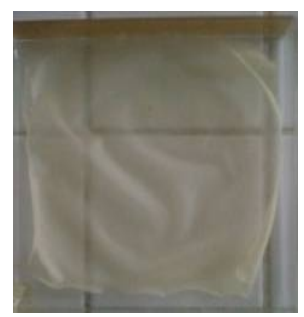

Membran KS-K(20:80)

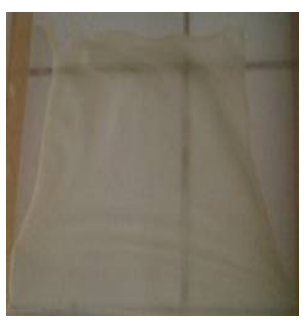

Membran KS-K(70:30)

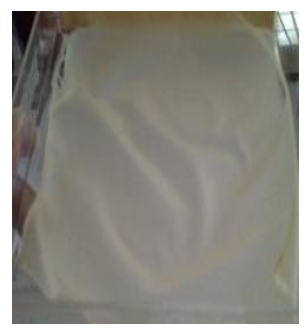

Membran KS-K(40:60)

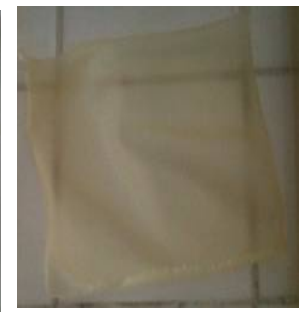

Membran KS-K(10:90)

Gambar 2. Membran kitosan suksinat-kitosan dengan berbagai variasi massa dalam \% (b/b) 
Karakteristik Membran Berbasis Kitosan Suksinat-Kitosan Terinsersi Litium

Kekuatan tarik erat kaitannya dengan sifat mekanik membran. Parameter ini penting karena menjadi pertimbangan dalam pemilihan membran dalam beberapa aplikasi seperti baterai polimer litium/LiPo. Sifat mekanik membran ini meliputi kekuatan, kekerasan, kekakuan dan elastisitas. Kekuatan mekanik membran kitosan suksinat-kitosan litium ditentukan melalui alat uji tarik Shimadzu, dengan kecepatan tarik $10 \mathrm{~mm} /$ menit, pada temparatur ruang. Selain itu, untuk menganalisis hubungan daya serap air terhadap sifat mekanik membran juga dilakukan penentuan daya serap air. Profil daya serap air membran berbasis paduan kitosan suksinat-kitosan terlihat pada Gambar 3.

Pada peningkatan fraksi massa kitosan suksinat sampai dengan $60 \%$ (b/b) pada membran menunjukkan penurunan daya serap air. Berdasarkan sifat mekanik membran berbasis paduan kitosan suksinat-kitosan, semakin kecil daya serap air terlihat kecenderungan pada peningkatan kuat tarik dan perpanjangan. Daya serap air pada membran berbasis paduan kitosan suksinat-kitosan terinsersi litium dengan fraksi massa kitosan suksinat hingga 70 dan $80 \%$ (b/b) memiliki daya serap air yang terendah.

Sehingga pada kondisi tersebut terlihat kecenderungan penurunan sifat mekanik berupa penurunan kuat putus dan perpanjangan serta meningkatnya Modulus Young. Hal ini diduga adanya interaksi kuat antara ion $\mathrm{Li}^{+}$dengan gugus $-\mathrm{COOH}$ pada kitosan suksinat dengan gugus $-\mathrm{NH}_{2}$ dari kitosan, sehingga membran menjadi lebih kaku. Profil kekuatan mekanik membran berbasis paduan kitosan suksinatkitosan terinsersi litium terlihat pada Gambar 4. Gambar tersebut menunjukkan bahwa peningkatan fraksi massa kitosan suksinat sampai dengan $60 \% \quad(\mathrm{~b} / \mathrm{b})$ cenderung meningkatkan kekuatan tarik dan perpanjangan, serta menurunkan Modulus Young. Perpanjangan sebesar $112,0 \%$, kuat putus 0,180 MPa dan Modulus Young sebesar 14,31 MPa. Namun demikian, pada fraksi massa kitosan suksinat 70 dan $80 \%$ (b/b), kekuatan tarik dan perpanjangan cenderung menurun,serta Modulus Young meningkat secara fisik membran dengan massa kitosan suksinat 80 dan $70 \%(\mathrm{~b} / \mathrm{b})$ hasilnya kurang baik, mudah sobek dan kaku. Hal ini didukung oleh data daya serap air.

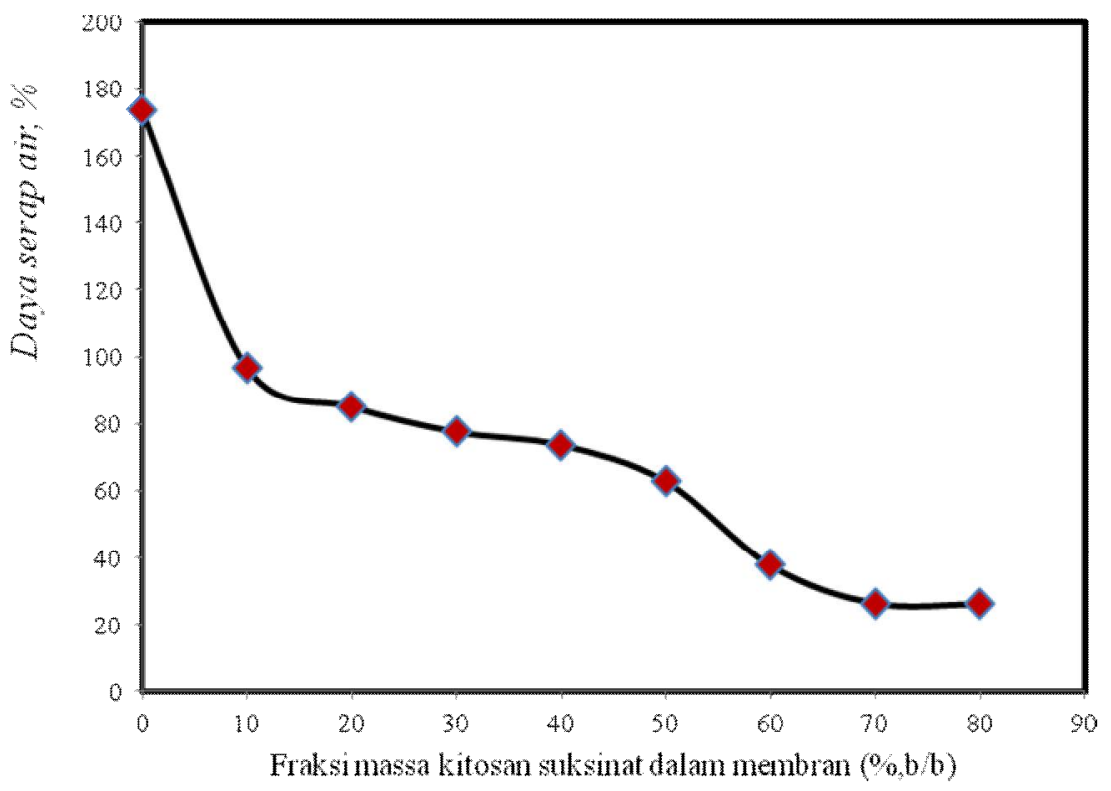

Gambar 3. Profil daya serap air membran berbasis kitosan suksinat-kitosan terinsersi litium 


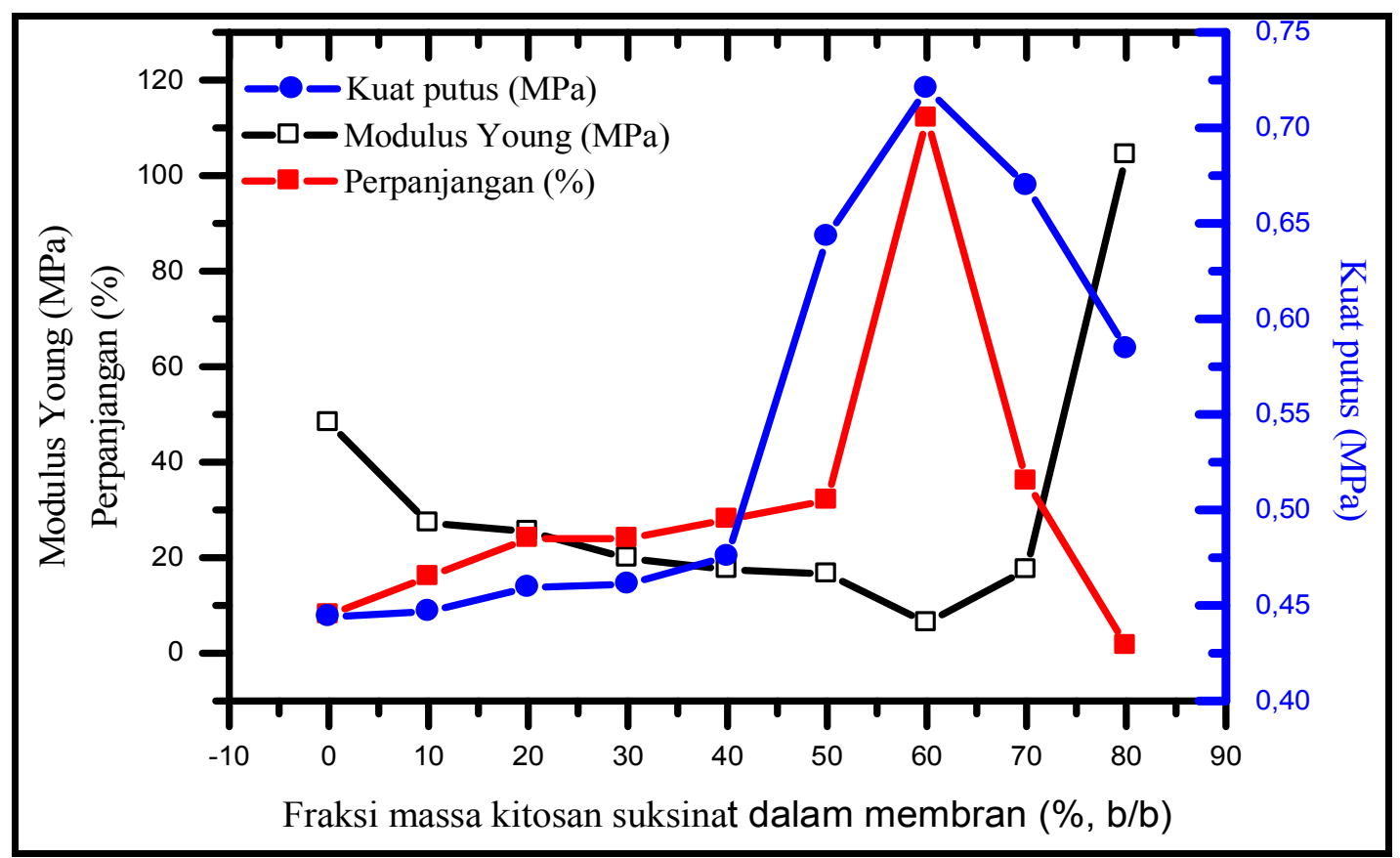

Gambar 4. Profil sifat mekanik membrane berbasis paduan kitosan suksinat- kitosan terinsersi litium

\section{KESIMPULAN}

Berdasarkan hasil analisis sifat mekanik, membran berbasis kitosan suksinat-kitosan terinsersi litium memiliki sifat mekanik yang cukup baik dan memiliki kekuatan tarik dan perpanjangan yang cenderung meningkat dan Modulus Young yang menurun.

\section{UCAPAN TERIMA KASIH}

Terimakasih kepada pihak Universitas Halu Oleo dan Dirjen DIKTI atas dana Hibah Bersaing sesuai kontrak No. 0633/PPK/UHO/2014.

\section{DAFTAR PUSTAKA}

Meyer, W. H. 1998. Polymer Electrolytes for Lithium-Ion Batteries, Max-Planck Institut fur Polymerforschung Ackermannweg 10. D-55128 Mainz Germany

Mohammed, N.S., R. H. Subban, And A.K. Arof. 1995. Polymer Batteries Febricated from Lithium Complexed Acetylated Chitosan. Journal Of Power Source 56: 153-156.

Mukoma, P., B. R. Jooste., H. C. M. And Vosloo. 2004. Synthesis and Characterization of Cross-Linked Chitosan Membranes for
Application as Alternative Proton Exchange Membrane Materials in Fuel Cells. Journal of Power Sources 136 : 1623.

Noerati, Cynthia, L. R., Saadijah, A., Dan Bambang, A. 2007. Sintesis Kitosan Suksinat Larut Air. Akta Kimindo 2 (2) : 113-116.

Ramadhan, L.O.A.N., Radiman, V. Suendo, D. Wahyuningrum, And S. Valiyaveettill. 2012. Syntesis and Characterization of Polyelectrolite Complex N-Succinyl chitosan-chitosan for Proton Exchange Membrane. Procedia Chemistry 4 : 144122.

Rinaudo, M. 2006. Chitin And Chitosan: Properties and applications. Progress in Polymer Science 31: 603-632.

Wan Y., K.A.M. Creber, B. Peppley B, V.T. Bui. 2003. Ionic conductivity and related properties of crosslinked chitosan membranes. Journal of Applied Polymer Science 89: 306-317.

Wan Y., K.A.M. Creber, B. Peppley B, V.T. Bui, 2003. Synthesis, characterization, ionic conductive properties of phosphorilated chitosan membranes. Macromolecular Chemistry and Physics 204: 306-317.

Winter, M., And J.R. Brood. 2004. What are batteries, fuel cells, and supercapasitors?. Chemical Reviews 104: 4245-4269. 
Xiao, Q., Zhaohui, Li, Deshu, Gao., Zhang H., A. 2009. Novel Sandwiched Membrane as Polymer Electrolyte for Application in
Lithium-Ion Battery. Journal of Membrane Science 326:260-264 